\title{
How the Waltz was Won: Transmutations and the Acquisition of Style in Early English Modern Ballroom Dancing \\ Part One: Waltzing Under Attack
}

\section{Abstract}

This two part article examines the contested transition in London's fashionable ballrooms from the established Victorian rotary waltz to the modern English waltz of the early 1920s. Existing scholarship on the dance culture of this period and locale has tended to focus on issues of national identity, gender, race, class and the institutionalisation of popular dance practices. Although these are of profound significance and are here integrated into the analysis, this fresh study focuses on the waltz's choreological aspects and relationship to its ballroom companions; on the dance backgrounds and agency of the waltz's most influential practitioners and advocates, and on the fruitful nexus between theatre, clubs, pedagogy, the press and competitions in transforming style and practice towards modern English ballroom dancing as both a social and artistic form.

Part One discusses the kinetic problems that waltzing couples encountered in the face of ragtime dances and tango, the impact of World War One on social dance practices in fashionable London and the response of the press and the dance pedagogic profession to the post-war dance craze. Improvisational strategies are considered as contributory factors in the waltz's muted persistence throughout the war while throwing light on how certain social choreomusical practices might lead to the transmutation of dances into newly recognised forms. The persuasive role of London-based leaders such as Philip Richardson, Madame Vandyck and Belle Harding in these early years of modern ballroom dancing is brought to fresh 
attention. Part One concludes with the dance teachers' inconclusive attempts during 1920-21 to define and recommend a waltz form compatible with both a discrete choreomusical identity and the stylistic dictates of modern ballroom dancing.

During the 1920s, a new way of performing couple dances, which quickly became known as the English style of modern ballroom dancing, was nurtured by an influential group of dancers and teachers in London's fashionable dance clubs and studios. Defined, structured and regulated by this professional and institutionalised elite, the English style of ballroom dancing gained international currency in the twentieth century. This controlled expansive dissemination was achieved through a transnational network of teachers, syllabi, examinations, competitions, demonstrations and performances that not only sought to modify this form of popular dancing in the social and recreational realm but also to recognise it as an art form. (1)

Within this reformulated modern repertoire of dances was the Waltz. This erstwhile staple of the English ballroom looked, in the early 1900s, to be losing ground against the perceived relentless invasion of African American sourced dances such as the Onestep and Foxtrot. Through various acts of conservation, promotion and innovation, however, the fight to retain the Waltz was won. In this labile process of shifts in and challenges to the Waltz's 'identity', the resultant transmutation was christened the English Waltz, its key characteristics having been established by the early 1920s. This study explores the contexts, mainly choreographic but also sociocultural, in which the Waltz was transformed from a 'traditional' to a 'modern' social dance in the turbulent years during and surrounding the First World War (1914-18). It is important to establish, of course, that it is more accurate to speak of 'Waltzes' 
rather than of 'the Waltz'. (2) Multiple and variant forms are a frequent characteristic of popular practices and it is vital to recognise that this dance form was never singular. For the purpose of clarity in this case study, however, the nomenclature of 'the Waltz' will generally be used to define the choreographic complex against other named dances in the contemporary ballroom repertoire. More detailed description of its changing manifestations forms part of the argument below.

My metaphor of the Waltz's recovery, retention and transmutation as a battle to be won, in part, suggests the struggle made by both amateur and professional dancers, teachers and others involved in the dance industry to continue dancing the Waltz against the influx of African American choreomusical practices. It also gestures towards the title of Christopher Tremewan Martin's doctoral thesis (2010) How the Waltz Has Won: Towards a Waltz Aesthetic which considers issues of ‘appropriation, neutralization and commodification' of ballroom dancing aesthetics principally using American sources between 1860-1915. Martin's research, in conjunction with that of Cook (1998, 1999), Gottschild (2000), George-Graves (2009) and Robinson (2006, 2009, 2010, 2015), makes a vital contribution to understanding of cultural power and racialised aesthetics in American popular dance during the early twentieth century, providing an essential context for the later developments and consolidation that took place in England and which form the focus here.

\section{Setting an Agenda for the English Waltz}

Before its institutionally approved codification, ballroom dancing in London during the First World War and immediately afterwards, constituted complexes of diverse practices that, in contrast to the provinces, were often fluid and hybrid in the social 
life of the fast moving capital. In and across these complexes, individuals and organisations exercised choreomusical preferences in competing to assert cultural (and often thereby economic) power. A principal aim was to render the English dance floor and its dancers more aesthetically uniform and orderly. But, as formulated in fashionable West End London, this imperative was not one that simply harked back to the nostalgically viewed harmonious ballroom of the nineteenthcentury Waltz; rather it was one which embraced and drove forwards a modernizing agenda for the nation's popular dances during the nascent era of jazz.

Over the past decade, this phenomenon of early twentieth-century English culture has drawn attention from numerous scholars outside the field of dance studies. Among the more sustained, informative and insightful analyses are the publications of social and cultural historian James J Nott : notably, his original and thoroughly grounded studies of the interwar recorded music industry and associated dance and music culture (2002), the politics and perceived moralities of London's 1920s nightclubs (2011), responses to the apparent Americanization of popular dance and music in the same decade (2013) and the culture of the palais de danse from 19181960 (2015). Social dancing of the period has similarly attracted social historian Allison Abra $(2009,2012,2017)$ who, like Nott, points up issues of class, culture, gender and nationalism, while literary historian Rishona Zimring (2013) approaches the topic through the lens of modernism. Geographer Tim Cresswell's essay (2006) highlights the standardisation of social dancing in England during the 1920s through a theoretical framework of cultural and corporeal geographies of mobility. Class, gender, standardisation, institutionalisation, cultural value, modernity, nationalism and race feature in all these studies as indeed in my own consideration, as a dance historian, of the so-called 'civilization' of the English dance floor (Buckland, 2011a: 
160-94;2011b).

Within academic discourse, the purposeful codification of popular dancing by an elite has regularly been analysed as a collusive strategy of cultural appropriation, economic advantage and socio-political control. (3) Such interpretations are justifiable, indeed often invited from the extant historical records pertaining to popular dancing and serve admirably to correct once pervasive notions of the apolitical and acultural nature of dancing. Arguably, however, in such revisionist treatments, other aspects of particular interest to dance specialists, such as considerations of choreographic form, genealogies of dance pedagogy and dancers' choreological perspectives, can often be side-lined or lost from view. While drawing upon the above scholars' findings and my own earlier work, this article expands scholarly knowledge of important drivers behind changes in fashionable social dancing in London of the early 1920s through a more dance-focused consideration of the sources.

The retention and transmutation of the Waltz (often referred to as the Valse in polite English circles well into the early twentieth century) is not without cultural and historiographical significance in the study of popular dancing. As the dominant couple dance form across Eurocentric society for more than a century, the Waltz carried symbolic resonance in cultural memory as the consummate dance of romance, variously purveyed and reinforced across music, theatre, the visual arts, literature and earlier embodied experience. The dance undoubtedly offers scope for separate scholarly treatment, to which existing literature testifies, (4) but a vital interest of this present study is also to advance analysis of how co-existing popular social dance forms might be transformed in certain conditions of metropolitan life. Rather than considering the Waltz's trajectory in isolation from other choreomusical 
innovations of the period, which indeed appeared to threaten its practice, the dance's fortunes in the early twentieth century are inextricably intertwined with its companions and rivals in the fashionable ballroom. In examining its early twentiethcentury discourse, my aims are twofold: first, to contextualise and interrogate the incorporation of the Waltz within the modern ballroom dance suite; and second, to examine the dance backgrounds, choreographic innovations and choices of key individuals in the overall transformation of ballroom dancing.

Factors propelling the early evolution of the modern ballroom repertoire were by no means unique to England or to the English. (5) France and the USA, in particular, Paris and New York, were important cultural nexuses in the generation and practice of new social choreomusical forms. Following the close of the First World War, however, as described in Philip Richardson's oft-cited preface to his history of modern ballroom dancing (1946):

England [...] undoubtedly [took] the lead in the development of modern ballroom dancing. Other countries may have supplied the raw material and the dancers of New York, being nearer the source of that material, may have been the first to experiment with it, but it was the teachers of England who first analysed the crude steps, reduced order out of chaos and evolved that modern technique which has made the English style paramount over three-fifths of the globe.

The professionally approved English ballroom repertoire from the mid 1920s constituted four principal dances: the Tango, the Foxtrot, the Quickstep and the 
Waltz. (6) As transatlantic newcomers to the English ballroom, the Tango, Foxtrot and Quickstep could trace choreo-musical lineages to African and Hispanic American culture. Hailing from Argentina and sanctioned by Parisian salons, the Tango enjoyed its greatest popularity in England during the dancing season of 1913. The Foxtrot, arriving more directly from America a year later, drew rapid popular attention and, later in the next decade, its close relative the Quickstep, highly influenced by the Charleston, evolved as a separate form. In contrast to the modish American provenance of these dances, the traditional Waltz professed an exclusively European ancestry. Long established as the dominant couple dance of nineteenth-century European society, the Waltz's roots were firmly in that continent and its chances of survival in modern England, confronted by ragtime and jazz in the first two decades of the twentieth century, were not propitious.

Towards the close of the First World War, Philip Richardson (1875-1963) as editor of The Dancing Times repeatedly feared for the Waltz's existence, so rare had its execution become in high-class London ballrooms. (7) Yet only some ten years later, a professional ballroom dancer, based at the stylish Carlton Hotel, commented on the Waltz's continuing presence on English fashionable dance floors that it was "odd how popular the waltz remains... it seems almost a [sic] heirloom handed down from generation to generation [emphasis in original]." (Scott-Atkinson, 1928: *] This apparent continuity amid an unstable period of social and aesthetic change poses questions of agency, creativity, form and value in popular dance. How did the supposedly moribund Waltz join company with the overtly modern repertoire of twentieth-century ballroom dancing? Who were the sponsors of its retention in English popular dance culture? And how did this continental import become designated as the English Waltz? This article focuses on the years from around 
1913 to the early 1920s, a time of considerable flux and diversity on the English dance floor, in order to address such questions of cultural retention, reformulation and reinterpretation in social dance practice.

The fact that the Waltz survived the various upheavals in English dance culture of the first two decades of the twentieth century and the disruption of the First World War was by no means incidental in the return to peacetime dancing. The Waltz had its vociferous apologists and foremost amongst these, circulating in almost ubiquitous manner, was Philip Richardson. Instrumental in pulling together leading dancers and teachers to a series of informal conferences (1920-21) in order to address issues in contemporary social dance practice, Richardson remained persuasive in shaping the direction of English ballroom dancing for several decades. (8) The pedagogic construction was primarily achieved from the mid 1920s through the work of the teachers of the ballroom branch of the Imperial Society of Dance Teachers (ISDT, from 1925 known as the Imperial Society of Teachers of Dancing [ISTD]), a branch whose 'origins...owe[d] everything to Philip Richardson (Cresswell, 2006: 66). Another noted main player in this process, as Cresswell discusses (2006: 66-71) was professional ballroom dancer, instructor and later band leader Victor Silvester (1900-1978) who helped to codify and disseminate the systematized dance technique through the auspices of the ballroom branch of the ISTD and whose chairman (1945-58) and president (1958-78) he subsequently became. (9) Fellow founding members of the ballroom branch were dancers and teachers Josephine Bradley (1893-1985) who first chaired the ballroom branch committee from 1924 to 1947, Eve Tynegate-Smith (ob. 1971), Georges Fontana (1894- 1965), Muriel Simmons (born 1890) and Mrs Lisle Humphreys (1892-1975). Enshrined in ballroom dance history, these names, more especially those of Silvester and Bradley, are 
testimony to the frequent observation that history is written by the victors, and their prominence in leading the later world of ballroom dance and music is undeniable. There were, however, other influential individuals during this initial period, such as Madame Vandyck (1876-1954), Belle Harding (c.1865-1945), Maurice Mouvet (1889-1927), G.K. Anderson (born 1887) and Alec MacKenzie (fl. in England 191228) whose activities and opinions need to be brought more directly into the historiographical frame in order to better illuminate practice and attitudes at this time. In the immediate aftermath of the First World War, it was by no means obvious who might successfully command a return to an orderly ballroom in which the old ideals of a European fashionable dance culture might prevail and in which the Waltz might recover something of its former prominent position. Contemporary sources indicate an assortment of practices generally on the dance floor in the post-war years and dissension in the recognition of discrete dance forms and their defining characteristics. Nor indeed was standardization a desirable and shared goal for all dance participants, especially when older style teachers insisted upon set choreographies for separately titled dances. (10) Furthermore, as Nott's research makes clear, many of the later professional pedagogic directives were often simply ignored by amateur dancers whose interests in dancing were primarily social in nature (2002: 162-63).

\section{Fashionable dancing on the brink of and during war}

Considerations of sociality for stepping onto the dance floor were of prime significance during the disruptive period of the First World War. The impact of those four years has been subject to numerous evaluations - military, political, economic, social and demographic - although with renewed interest arising around the 
centenary commemorations, questions in the debate have been both reiterated and extended. As historians Aviel Roshwald and Richard Stites (1999: 1) have posed:

Did the war catalyze and accelerate tendencies that were bound to rise to prominence in any case or did it decisively change the course of historical evolution? Was its cultural impact as clearly discernible as its material consequences?

Few historians, although engaging with the cultural realm, have dwelt much upon the impact of war on social dancing within their remit. (11) Yet the role of dancing was not inconsequential in wartime popular culture.

The voluntary response of so many young men to the call to arms, the restrictions imposed by the government on civilian life through DORA (the Defence of the Realm Act) and the view that dancing was a frivolity in the face of so much tragic loss undoubtedly curtailed both appetite and opportunity to dance. (12) This was, though, by no means a uniform response. Indeed, it may appear surprising that so much dancing did take place at different times during the four- year period of the war. Dancing often functioned as a means to raise war charity funds, to maintain the spirits of those working on the home front, to provide a social context for soldiers on leave to enjoy a semblance of normality with family and friends and increasingly to help rehabilitate the sick and wounded. For many families meeting up to dance with their soldier sons, the Waltz remained a familiar point of contact. Such intergenerational practice served to maintain its manifestation on the dance floor, even if 
the technical competence of its dancers was considered in certain influential quarters to be well below par.

Prior to the war, there had been two dominant modes of dancing to Waltz music in fashionable urban ballrooms: the older nineteenth-century rotary Waltz in which the man and woman stood opposite one another in ballroom hold and progressed around the ballroom taking one step, rising and falling with feet slightly turned out, to each beat of the bar; and the newer less widely disseminated linear form called the Boston where the couple stood hip to hip, the man facing the line of direction of the dancing, sometimes cutting diagonally across the floor, while moving smoothly to the melody rather than on the clear beats of the triple metre. (13) This latter mode of waltzing required considerable space in which to perform, a choreographic feature that largely contributed to the form's demise on crowded dance floors. Performed to the early twentieth-century resurgence in Waltz music by English composers, it was essentially a slow style of waltzing in which rapid twirling and fixed steps to each beat of the $3 / 4$ bar were replaced by an improvisational association with space and time. This feature was shared with the new ragtime dances and those that soon followed such as the Tango and Foxtrot.

The Boston remained in vogue in the spacious fashionable ballrooms of London's West End until around 1913, when it literally gave ground to the less space-hungry ragtime dances, such as the One-Step and the Tango. The One-Step, as its name suggests, removed any obvious need for specialist dance tuition, inviting dancers onto the floor to walk beat for beat, 'ragging' and spinning rapidly to its driving $2 / 4$ syncopated rhythm. (14) It continued to be popular throughout the war and in the immediate years afterwards. To its driving ragtime rhythm "the only thing one could do was to walk, which we all did with energy and enthusiasm" (Bradley 1947: 16) It 
did, at least, conform to the traditional 'round dance' progression of couples circling around the perimeter of the room even if dancers frequently stopped in their tracks to step sideways, backwards or even halted completely.

The Tango, on the other hand, in its pre-war Argentine form translated for Parisian salons and restaurants and exported to London, did not always progress around the room and required expert teaching. Its confusing plethora of steps and figures contributed to potential chaos on the dance floor as dancers trained by different teachers often found insufficient common knowledge to improvise successfully as a couple. Dancing master Edward Scott's skit 'The Tango', based on William Blake's well-known poem 'The Tyger' epitomises conservative reaction to the new choreomusical introduction:

Tango, tango, turning tight

In the salons of the night;

What distorted hand or eye

Framed thy wrigglings all awry?

And what strange ideas of art

Must be theirs who take a part

In thy music's walking beat,

Writhing with entangled feet. (15)

Aside from Scott's clear distaste for the close body contact in the Argentine tango is

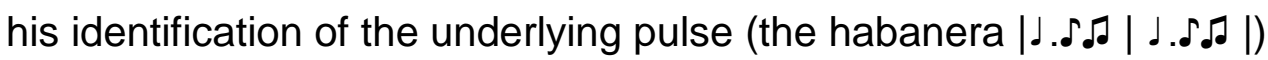


which acted as a rhythmic imperative to walk while keeping close contact with the floor (slow quick quick) rather than to rise and fall liltingly on the balls of the feet as in the late Victorian Waltz step espoused by Scott. (16) Concluding his parody with the question 'Can they who loved the waltz love thee?' Scott suggests not only traditionalist disaffection with the Tango's use of space, time and bodily proxemics but also points to a ballroom where a new social choreography threatens - one which does not meet established criteria of the long-hallowed cultural distinction between the art of dancing and locomotion in general. Walking, as categorized in Scott's aesthetic understanding, was most certainly not art.

A distinct preference for less complicated dances, however, was gaining fashionable currency, ousting even the Argentine Tango in favour of the latest novelty, the Foxtrot. Indeed, the names of this wave of pre-war social dances as in 'step' and 'trot' are indicative of their shared trait with the Tango, particularly in its post-war Parisian form, as 'almost walking dances'. (17) These comparatively easy dances were perfectly suited to a war-time clientele, which frequently included soldiers on leave, unable to attend regular dance classes, keen to be up to date and to focus on the sociability that such simple 'go-as-you please' dances afforded. The sprightly 4/4 of the popular Foxtrot encouraged a wide range of perambulatory movements from the simple combination of walking for a bar followed by quick runs or trots in the next two bars to more demanding and exuberant variations including small leaps, kicks, and hops. (18)

Most metropolitan teachers needed to be abreast of such developments, even if they disagreed with what they regarded as bad dancing. In order to attract and maintain their clientele of social dancers, fluency in topical dance styles was essential. Some West End teachers, however, did not act as mere conduits for 
popular choreographic innovations to pass on to their paying pupils. For several years before the agreed codifications of the ISTD ballroom branch, some influential teachers had taken a more active role, one which has often been minimized or indeed forgotten, in the genealogies of ballroom dance evolution and pedagogy. During the war years and immediately afterwards, London-based teachers such as Belle Harding and Madame Vandyck among others helped steer stylistic elements of deportment and dynamics from an earlier age into the emergent mode of dancing. In addition to their tuition, they organized dances where the latest fashions, approved by them, could be practised socially. Significantly, leading Society teachers retained some Waltzes on their programmes. In 1916, for example, Richardson advised a soldier on leave who complained at the dearth of Waltzes played at the dance venues of the Savoy, Ciro's and Murray's to attend Miss Belle Harding's [see Figure ] dances at the Waldorf Hotel (in Aldwych) or those of Madame Vandyck at Harewood Place (near Oxford Circus). (19) Richardson was clearly in sympathy. In his editorial in December 1918 (p. 59), the "Sitter Out" [usually Richardson himself] hoped for the return of the pre-war 'normal' dance music of Joyce, Godin and Corelli-Windeatt who, of course, specialized in flowing strings-dominated melodies rather than the syncopated sounds of the new dance bands, which, banjos prevailing, Richardson declared incapable of performing waltzes for dancing. The editor's partiality among the current dances was clear: 'I like the rag, I like the foxtrot - but I love the valse." (20)

The Waltz was still performed, if very occasionally, in London's fashionable centres, particularly in its new guise of the Hesitation Waltz which became popular in London from 1915. The new Waltz tunes from America, referred to as ragtime, syncopated or hesitation Waltzes, were often in accord with the upbeat tempo of the rag. To 
each two bars of Waltz music, the dancers performed four consecutive steps, pausing on the final two beats, thus giving rise to the name of 'hesitation.'

Interestingly, Richardson locates the evolution of the Hesitation Waltz (1946, p. 21) in the pre-war Tango Valse which arose from a combination of the Boston and the corte step of the Argentine Tango then current. Rather than an American invention, the Hesitation Waltz, Richardson averred, was the inevitable result of dancers performing Tango steps to Waltz music. (21) This tendency by dancers to apply what they knew or enjoyed to any music being played in the ballroom is testimony both to the improvisational nature of the new dances and, now growing in voguish acceptance, to a freer relationship between the music and dance that suggests an eschewal of separate choreomusical identities.

\section{An Improvisational Practice: the Waltz within the Saunter}

If, in fashionable London during the first two decades of the twentieth century, the Waltz rarely figured as a discrete dance (as identified by its champions as a constellation of $3 / 4$ rhythm, a specific stepping pattern and rotation of the dancing couple) elements of the nineteenth-century Waltz were nonetheless recognizable in improvisational practice on the contemporary dance floor. A short digression on the Saunter is necessary at this point in order to identify these possible traces of the old Waltz within the embodied memories and practice of wartime dancers who later contributed towards the Waltz's reformulation.

Ever since the arrival of the Waltz in the early 1800s, new dancing seasons had brought expectant hopes of new dances, ideally distinct in form, character and rhythm; but after 1915 nothing immediately appeared to supplant the Foxtrot, the One-step and the Hesitation Waltz. By 1916, however, there had arisen a 
discernible style of improvising among ballroom dancers at the Savoy and Waldorf Hotels, as well as at Ciro's and Murray's Clubs. Christening this seemingly emergent new dance' The Saunter', Richardson, through the columns of The Dancing Times, invited teachers to comment on his description of the dance as a 'delightful mélange' of various old favourites such as the 'quiet movements of the fox trot, the dear old round valse, the hesitation, the two step and even some tango' rather than a uniquely fresh form. (22). It is proof of Richardson's far reaching influence and standing that his proposed name for this apparent new form was quickly accepted by the dance profession, while the sheet music of the favoured tune, a composition in slow 2/4 by Herbert Spencer called 'Underneath the Stars' was soon marketed as a 'Saunter' by its music publishers Francis, Day and Hunter. (23) Leading teachers - Madame Vandyck, Miss Harding and Mrs Mackenzie -were largely in agreement with Richardson, pointing up the slow romantic tune and consequential quiet, smooth and elegant dance as a welcome contrast to the energetic pace of the Foxtrot and Onestep. Harding, ever at the forefront of new developments, had already showcased the Saunter in July 1916 and even organized a competition for the best Saunter new tune in an effort to promote this smoother style in which Waltz steps might be employed. (24) Madame Vandyck [see Figure 2] claimed that she had already been teaching this way of dancing for several months under the name of Foxtrot as an improvement on what she regarded was otherwise an 'exceedingly ugly dance' with its 'trotting' and 'hideous' shoulder and arm movements (no doubt a 'shimmie'). (25) Musical theatre star and keen ballroom dancer Phyllis Monckman likewise commented that Richardson had 'only given a name and drawn attention to a habit of which I have been very fond for a long time', professing that she had always danced the Foxtrot in 
a smooth fashion in company with steps from other dances such as the Valse and Tango. (26) Through this means, a corporeal performing memory was in operation. This emphasis on the dancers' freedom to react individually to the music was the hallmark of high-class London teachers, in marked contrast to conservative provincial teachers for whom 'an enjoyable and harmonious dance is for all dancers to execute the same steps in the same rhythm and the same order.' (27). Such regimented repetition, however, smacked of Victorian conformity, ill-suited to a leisured class of affluent dancers who responded almost nightly to the exciting new sounds of ragtime bands playing in select West End venues. A new pedagogic approach was needed, as Madame Vandyck explained:

no ball-room must be taught in 'bars.' A man must be taught to express the rhythm of the music. When he reaches that stage, he will quickly learn to invent his own variations. A girl must likewise be taught to feel the music, and be an echo of her partner and follow his movements without any ideas of her own upon the subject. Only in this way can you dance what you so aptly call 'The Saunter,' or, in fact, any other modern dance. My pupils are always taught on these lines... (28)

The possibility for men to exercise individual choice, demonstrate skill and thereby attract female partners in the ballroom, had already rekindled dwindling high society male interest in social dancing (much complained about in the late Victorian period) through the arrival of the Boston, Tango, and ragtime dances. Now the Saunter 
provided fresh opportunity for romantic closeness in a style reminiscent of the Waltz whose steps might be incorporated into the improvisation. Furthermore, its musical accompaniment, played by a string orchestra, was closer in texture and melodic flow to pre-war time Waltz music than to ragtime. But its popularity was to be short-lived in the wake of fresh trends already discernible in the rag music of visiting American bands which was morphing into what, in England, would later be branded as jazz. This new sound for dancing was in hot demand in the progressive nightlife of the affluent West End where the music of the Foxtrot eclipsed that of the Waltz.

\section{Early Jazzing in the West End}

It was in key West End venues, among a particular clientele, where transmutations in social dancing were forged that were to lead to the formulation of the modern English ballroom repertoire. London's public restaurants, hotels, and private nightclubs - the latter a new and rapidly growing phenomenon introduced just before the First World War - provided essential arenas for play and for networking among a metropolitan patronage of prosperous and socially well-connected individuals. City bankers and financiers, business men, socialites, aristocrats, stage celebrities, and dance and music professionals met often nightly (and for many during the afternoon and early evening) not only to enjoy food, drink, cabaret entertainment and, possibly illegal substances, but also to dance to the latest music. There were numerous clubs offering dancing spaces in London's West End: among the most select and fashionable were Murray's Club in Beak Street [see Figure 3] Ciro's in Orange Street, Leicester Square, the Grafton Galleries in Grafton Street, the Embassy Club (formerly the Four Hundred) in Old Bond Street and Rector's Club in Tottenham Court Road. Access was only for the financially and socially privileged. The Dancing 
World in its feature on Murray's club (Anon., 1920) remarked that it "was not easy to become a member of Murrays, for one must be nominated by two members and be approved by a Committee." Dining at the Embassy Club, famed for its luxurious décor and high- class cuisine, was typically followed at midnight by dancing at the Grafton Galleries to the 'rhythmical and quiet music' (Bradley, 1947: 13) of the Versatile Four who had earlier been playing at Murray's. (29) The comparative proximity of these venues to one another plus the late opening hours afforded abundant potential for talented dancers to practise with different partners, imitate and experiment. 'Improvisation was rife' recalled Josephine Bradley (1946: 13), especially at Murray's Club 'the meeting-ground for the smart set of London'. Here, as one provincial visitor noted, the dancing 'was very good, indeed, as is usually the case at any night club where most couples are more or less specialists.' (30) To his disappointment, however, only one Waltz was played during the evening, quite unlike the dancing scene in Liverpool.

Waltzes were still being played in London by established English dance bands such as those led by Stanley Holt (Public Schools Dances) and Archibald Joyce (Boston Club Dances). In the new night clubs, African-American bands, notably the Versatile Four at Murray's and Ciro's Club Coon Orchestra (as titled in the language of the day) rarely played them, preferring rags and foxtrot numbers. Both of these bands, however, were well-seasoned accompanists for dancing. They included former members of James Reese Europe's Orchestra which had played for the celebrated exhibition ballroom dancing of Irene and Vernon Castle and, in the case of Ciro's orchestra, also that of well-known New York ballroom dancer Joan Sawyer. (31) The loud and often raucous sound of the dance music of the club scene, was often deliberately cultivated for the sake of novelty, as in the case of the all-white 
American seven piece orchestra, the Original Dixieland Jazz band which played at Ciro's from 1919 and eventually became the resident band at the more democratically accessible but no less fashionable Hammersmith Palais de Danse. (32) Banjos, as well as drums and piano, were prominent in the early jazz bands, furnishing both melodic and rhythmic energy which in the Dancing Times' view promoted many dancers to execute what it regarded, again in the parlance of the times, as "nigger steps." (33) There was little doubt in the minds of critics that the exuberance of jazz belied African sources and that this style of music was fundamentally alien to the perceived English temperament. The issue of racialised aesthetics was to be an important determinant in the progress of the Waltz's return (see below).

Confusion reigned, however, in the immediate post-war period, as to what precisely this label of 'jazz' meant. Contemporary discourse from 1917-1920 and indeed, some years later, indicate that the terms 'jazz' and 'jazzing' were used in England to designate both the musical form and a supposed specific dance. Bands, for example, typically composed of trap drum, piano, clarinet, trombone and banjo, were frequently identified under the label of jazz, regardless of what and how they played. And, for several months following the autumn of 1918 there was a supposed new dance form known as the Jazz Roll. (34) Those without ready access to the nightclubs of the West End needed enlightenment and the following year dancing teacher London-based Monsieur Pierre brought out a manual of instruction. How to Jazz. A Simple Guide to the 1919 Dances contains descriptions of the already established 'One-step or Rag' and 'Hesitation Valse', together with the 'Jazz Valse' and a tellingly labelled 'The Jazz or 1919 Fox Trot' - ' a three-step dance done to four beat time' (1919: 7) which incorporated steps which Pierre calls 'the 
Straight Jazz', 'the Jazz-Roll' and 'Tango Jazz-Roll.' Such nomenclature not only points to the imperative to deliver the latest dance fashions of the jazz but also underlines the fluidity of practice across what were hitherto distinct dance forms and rhythms. The Jazz Roll did not actually constitute a new dance form but rather was a motif or step- a variant of the Straight Jazz which was a repeated pattern of three gliding walks either forwards or backwards but which could also be taken alternately to the side (called the Side Jazz) or if taken diagonally it 'somewhat resemble [d]the old Boston step' (1919: 10) and could be used to negotiate the corners of the room. A more popular variant of the Jazz Roll involved the leading foot crossing slightly over the other, the shoulders swinging into the direction of the movement (35) as the couple aimed to move as one entity either forwards or backwards "in continuous curves." The alternate swings of the same shoulder of the crossing foot on the initial step, when executed smoothly and incessantly, helped to suggest "the motion of a boat on a rough sea." (36) The long gliding steps (slow, quick, quick) according to Bradley (1946: 12) heralded the beginnings of the later English style. By the summer of 1919, the Jazz Roll, now most often referred to as the three-step, had lost the rolling cross-over move. As the three-step, this pattern became free-floating in the sense that dancers drew upon it in the Hesitation Waltz, One-step and Fox-trot. Its appearance across all dances, however, was not viewed favourably by everyone. Richardson opined that the three-step should be kept to the Foxtrot as its ubiquitous use 'debars the user from feeling the glorious swing and lilt of the true valse' noting that '[I]t is essentially the step of the younger generation, of the young man who has been too busy during the past five years to learn how to valse.' (37) Meanwhile, at the private Murray's Club, a number of characteristic later features of the English ballroom dance style were developing in the immediate post-war years. 
The briefly fashionable "clinging vine" mode of holding the partner where the man pressed his head onto the top of that of his partner, their extended arms held aloft, (38) had been replaced by a hold more comparable with present day social ballroom dance, though the manner of the woman's fingertips resting on her partner's shoulder, wrist raised, was not to be later endorsed. (39) Other new features in dancing style were to be seen in the West End. Not only was it at Murray's that the Jazz Roll was reputedly first danced in London but also a turn in which the feet passed one another rather than closing on the third step, a figure later known as an 'Open Turn." Both moves were attributed to an amateur dancer, a 'City magnate' Mr Morgan whose apparent inventions bore his name, viz. the Morgan Roll and the Morgan Turn. (40) The club was also frequented by G. K. Anderson, who together with Josephine Bradley was to help cement the basics of the English style, largely through their renowned execution of the Foxtrot. The popularity of the 4/4 tunes, the habit of walking to the music and growing expertise in the new improvisational practices that played across once sacrosanct boundaries of kinetic and musical measures . (41) all contributed to the decline of the old Waltz and with it, in some eyes, the decline in good dancing. There was no loss of eagerness though for getting on the dance floor; indeed, quite the contrary, but there was much discontent voiced by stakeholders in the dance profession and by the press about the ensuing standards of execution outside the West End fashionable dancing circuit.

\section{Pressures on the Dance Floor}

Across much of the population, dancing had proved an immediate outlet for communal expressions of joy at the end of war in 1918. There was widespread recognition and, for the most part, approval of this immense enthusiasm: dancing 
teachers, leading exhibition ballroom dancers, devotees of old style manners of dancing, commentators in specialist periodicals and in the local and national press all reported on and benefitted from the renewed and burgeoning dance craze that swept the nation. At the same time there were countless complaints against the alleged deterioration in standards of dancing, especially in the case of waltzing. Undoubtedly there was media tendency to exaggerate such claims, whilst the creation of economic opportunities for those within the dance profession also needs to be borne in mind when evaluating this condemnation of technical proficiency. Alarm over a supposed degeneration in dancing and often associated moral standards had been a familiar trope of social commentators, the teaching profession and, increasingly, a press that was ever keen to benefit from increased sales of salacious copy and to fan the flames of the latest moral panic to which new dance fashions gave rise. (42)

From the practised dancer's perspective, however, there were genuine problems in the contemporary ballroom, particularly for those who wanted to continue to enjoy the Waltz. High on the list of potential reforms was encouragement of strategies to promote a harmonious atmosphere and environment in which dancers could enjoy participation without threat of being kicked or of collisions between couples on the dance floor. These issues were not entirely attributable to thoughtless or untrained dancers but often resulted from the choreography and improvisational nature of the dance itself. The hesitation step from which the wartime Waltz took its name, if judiciously used, prevented dancers from tiring too rapidly, but if executed too frequently or in too exaggerated a fashion without due regard for the space of others, could cause discomfort to and confrontation with other couples. Rapid spinning in the Onestep was another bugbear of more skilled or socially responsive 
dancers, as this figure prevented couples from progressing around the room at the same rate. (43)

Another choreographic impediment to progression around the room was the popular ending to the side-step that involved an abrupt halt, poised on one leg, the other kicked up from the knee behind. Even the Hesitation Valse, as popularly danced in England, reputedly favoured a hesitation variation that ended 'with the ... foot suspended in the air' (Cree, 1920: 43). 'Dips' and 'twinkles' were similarly viewed with disquiet: in the former, the couple lunged forwards together in a promenade hold [see Figure 4) while in the latter the couple might, without warning, step quickly backwards, close their feet together and then step forwards again. The aggravation this caused to other dancers was compounded by the fact that the twinkle might be taken in any direction. 'Forward -- always forward' urged Richardson (1919: 83), pleading for better dancing and consideration in the ballroom. These steps were arguably the least troublesome of what the press and teachers categorised as 'freakish steps'. More problematic were the challenging moves typically copied from the routines of exhibition ballroom dancers on the stage, in restaurants and clubs. The early Foxtrot in its very fluid and fast versions was a magnet for such showy steps and an arena for experimentation. Bradley refers to a dramatic step, for example, known as the Flying Angel, in which the man "threw me in the air with the right leg, and brought me safely to earth again by catching me on the same leg." (1947: 21).

The desire to police such excesses, to drive a clear line between the spectacular and the social was brought to a head on the return of demobbed soldiers for many of whom, and for civilians, dancing was now "the safety valve of five years' concentrated nervous strain." (Sweetsur, 1920: 7). Cast as an antidote to modern 
extremes and as a supposed link with earlier more civilized times, the Waltz came, in those post war years, to assume renewed significance as a symbol of cultural continuity and as a practical contribution towards control on the English dance floor.

\section{Arguments for Retaining the Waltz}

In the professional and popular press, the return to and retention of the Waltz was argued on a number of grounds: instructional, nostalgic, corporeal, and aesthetic. Repeatedly, Richardson used his influence as a journalist to record instances of waltzing and to advance arguments in its favour. Early in 1919, for example, he encouragingly reported on composer and conductor Archibald Joyce's rendition of a Waltz that drew 'prolonged applause' from the members of the Knightsbridge Hotel's Boston Club, (given the club's specialist title, it was undoubtedly predisposed to appreciation of some version of the Waltz) and commented that it was again "delightful to swing round the room to a string band." (44) Further evidence of the Waltz regaining ground on London's fashionable dance floors, he argued, lay in the increased demand from dancers for its inclusion on programmes and a more widespread tendency to introduce 'valse steps' into Foxtrots and Onesteps. In November 1918, following an invitation to dancers and teachers to compare preand post war ball-room dancing, Richardson published positive responses on the Waltz including, for instance, that of well known musical comedy actress and dancer Ivy Shilling. Arguably an expert witness as a frequenter of London's fashionable nightlife, she asserted that the 'valse' was the 'foundation of modern ball-room dancing' (45) Author of a 1920 ballroom dance manual A. M. Cree agreed. Referring to the Waltz (page 39) somewhat nostalgically as the 'Queen of Dances' he offered, in authoritative and biblical language, the following advice: 
Learn the valse perfectly, and all other Dances will be added unto you. And until you do know the valse do not try to learn any other dances.

Returning young soldiers, however, had little if any previous training or seasoned experience on the dance floor, never mind specific knowledge of the Waltz stepping pattern.

Overcrowding in the dance halls also compromised the particular experience of the Waltz not only in limiting its correct execution, but also disabling the distinctive pleasurable visceral experience afforded by the potential to achieve an expansive swing in turning..(46) This desirable sensation could only emerge if the male dancer knew how to navigate himself and his partner around the room. The decline in transferable corporeal knowledge of this technique often resulted in a

great deal of bitterness ... frequently ... present at public dances on account of continual collisions, on the part of bad dancers, due to a want of knowledge in steering.(47)

This observer also remarked upon the ballroom hold, noting a return to that prevailing in the nineteenth century where the man and woman faced one another. During the First World War, this familiar position had often been replaced by one in which the couple both faced the line of direction of dance, as often seen in the Tango of the time (later and today known as promenade hold) and which facilitated forwards progression in a straight line. (48) Such a position, however, prevented the 
easy rotation of the couple while travelling around the room in the typical round dance pattern of waltzing. By this time, not only was the notion of a discrete Waltz step in $3 / 4$ time in severe decline but so too was the Waltz's main characteristic as a continuously turning dance.

As Josephine Bradley (1947: 16) recalled:

When a waltz was played, everyone looked dreamy-eyed, and said: "Ah, the waltz but went on the floor and did exactly what they did in the foxtrot.

Her memory accords with a contemporary instructional text that speaks of 'the more popular method of dancing the Waltz, that is, executing all the Fox-trot movements to the waltz tune.' (An Expert, 1923:15). By late 1919, any semblance of separate choreographies was actually very confused in practice, leading Richardson to lament that in the contemporary execution of the three principal dances - the Hesitation Waltz, the Foxtrot and the Onestep - 'it is difficult to say where the one begins and the other leaves off.' (49) This indiscriminate blending of steps and rhythms offended dance pedagogues who were obviously keen to distinguish between the dances for professional reasons, both aesthetic and economic. It was also a point of regret for social dancers who hoped, during the evening's programme, to experience rhythmic and choreographic contrast.

By 1919 , the Valse, reputedly 'making headway' as it crept back into the ballroom, was played at a less hurried pace than during the war.(50) The slower tempo acted as physical respite from the energy of the Rag and also relieved the monotony of successive Rags and Foxtrots. Any tendency, however, towards great contrast in 
slowing the Waltz's speed was not altogether compatible with good dancing, at least not in Richardson's assessment.

One problem he identified was the likelihood of younger dancers using the slower pace to introduce spectacular steps or to make the delay in the hesitation step even more pronounced. He also complained of the 'dirge-like manner' of playing the music that was common in London dancing halls: a speed which in his opinion hampered proper experience of the dance, even if it might facilitate correct technical positioning of the feet. Unusually, he awarded the palm for good waltzing to the north of England where the music was taken at a slightly faster pace but not at the hectic levels of earlier in the decade. (51) Correspondence published in the Dancing Times confirms geographical differentiation in the tempi of ballroom dances. In the case of the Waltz, J. Woof Gaggs, musical conductor at the Blackpool Tower, recommended 55-60 bars per minute (BPM).(52)This Lancashire pace corresponds with that of Bolton musical director and dancing master Mr. R. T. Almond of the BATD who similarly advocated 60 BPM. In Nottingham, however, 52 BPM was preferred by musical director Mrs A E Roscoe. Whereas different tempi for ballroom dances prevailed in London and Scotland, there was a greater degree of conformity across the "Midlands, Lancashire, Yorkshire and the North" which corresponded with those performed at Blackpool. This is not surprising given Blackpool's growing premier position as a very popular seaside resort noted for social and competitive dances, drawing most of its holiday makers from those regions. (53) In London, however, the decrease in the Waltz's speed, alongside that played for the Foxtrot (now morphing towards the slow Foxtrot more comparable with today's practice) encouraged a longer stride, contributing to the formation of the distinctive English ball-room style. 


\section{Towards Pedagogic Policing: The Grafton Galleries Informal Conferences}

\section{$1920-21$}

Improvisation by well-practised dancers competing against one another in the smart West End clubs contrasted with the situation on most metropolitan dance floors where lack of engagement with teachers and with models of terpsichorean restraint and polish was evident and frequently bemoaned by the press and dance profession. 'Taming' such exuberance and, in the eyes of teachers such ignorance, was where the existing pedagogic industry might offer its services. In 1920 Richardson published a letter from Maurice Mouvet, the renowned international exhibition dancer suggesting that dance teachers follow the example of their American counterparts in uniting to standardise the steps of the new dances. (54)) The first informal conference led by Richardson, advertised via the Dancing Times, was held at the Grafton Galleries in May 1920. It attracted around two hundred teachers. Demonstrations by Maurice, as he was often simply known, and his then partner Leonora Hughes (born 1897) were followed by discussion of desirable changes to eliminate the current ballroom dance behaviour that Richardson labelled 'artistic bolshevism'. The conference approved Edward Scott's motion that the teachers present should

do their very best to stamp out freak steps in the ballroom, particularly dips and steps in which the feet are raised high off the ground, and also side-steps and pauses which impede the progress of couples who may be following. (55) 
High profile coverage of the event and recommendations by the Daily Mail and elsewhere in the media industry, supported the teachers' cause. The issue provided good copy, combining national interest and participation in dancing, the glamour of celebrity and fashion, potential for sensational reporting and a moral crusade. More detailed choreographic concerns, however, needed to be addressed by the dance teachers gathered at the conference from among whom a select committee of fifteen, chaired by Philip Richardson, was charged to "consider which shall be the recognized steps of each dance, and...report their decision to a general meeting." (56)

The composition of this first committee suggests a blend of established pedagogic experience, knowledge of the latest developments in social dancing on the dance floor, international viewpoints from leading exhibition dancers and potential for input from both male and female perspectives, although the balance was in the male favour. All the committee members were well-known in the dance profession and served as teachers and/or performers to a London-based clientele, more specifically to the higher end of society. On the international performance and teaching front were Maurice himself as well as younger exhibition dancer Georges Fontana. The oldest continuous lineage of teaching dance and deportment to royalty and high society lay in the person of Mrs Louis D’Egville (born 1854) her better known husband having long turned his back on social dancing following the arrival of African American dance and music (see Buckland 2011a: 195-96). Also well known as a Society teacher, if not quite so high in the social scale, was London teacher Charles D'Albert (1858 -1923) who, in addition to being a secretary of the ISDT and editor of its journal before the war, was the author of numerous articles and of two 
editions of an encyclopedia of dance $(1913,1919)$. He also had a history of international pedagogic connections (57).

Some committee members had specialist expertise in one particular dance form such as Edward Scott (1852-1937) in the Waltz (see Buckland, 2003). More familiar with the new dances was teacher Muriel Simmons (born c. 1890), head assistant for fashionable Parisian dancing master Monsieur Robert, who was well informed in the latest version of the Tango. (58) Of a similar generation was Alec Mackenzie, who with his wife, ran a well-regarded London school from 1912 specializing in the latest dances. (59) Edinburgh and London-based dancing master Donald G.MacLennan (1869-1965) not only brought potential Scottish interests to bear but more significantly was the first UK teacher to demonstrate the American version of the Foxtrot to the British pedagogic profession in 1915. (60) As noted above, experienced teachers Miss Belle Harding and Madame Alice Vandyck ran highly influential London schools with numerous assistants and also exercised both national and international reach, extending to the European continent and in the latter case Egypt. (61) Interests of more conservative enterprises and a slightly less well-heeled clientele were apparent through W. F Hurndall (1858 -1925) a London dancing master well-known for his invention of sequence dances. In addition, he was a keen advocate of working together to "get a uniform method of teaching and dancing which would benefit the public and all teachers of dancing."(62) Representatives of national dance teaching organisations were London based Harry Bloodworth of the National Association of Teachers of Dancing (founded 1907) and Major Cecil Taylor, an established member of the pedagogic profession, who was later to drive forwards the agenda of the various branches of the ISTD and whose presidency he was to occupy from 1909 until 1945. 
Although a number of these teachers no doubt brought together their knowledge of specific dance forms, organisations, gendered kinetic understanding and performance contexts, it is important also to remember that several shared dance expertise beyond modern social dancing. Hurndall, Bloodworth and Taylor were all teachers and composers of the older genre of sequence dances (Buckland 2011a: 187-88). Madame Edith Baird offered classes in Greek dancing in addition to social and operatic dancing; Maclennan came from a famous family dynasty of Highland pipers and dancers, while Madame Jeanie Smurthwaite was also noted for her tuition in operatic dancing (i.e. ballet). (63) Markedly all members of the committee were white professionals who operated in moneyed circles. And whether by design or accident, Richardson chaired an intergenerational committee the ages of whose members ranged from their late sixties through to their early thirties.

Presenting the findings of the committee, which had deliberated in two long meetings, to the second informal conference at the Grafton Galleries in October 1920 proved more contentious, especially with respect to the Tango, a form in which English teachers were less practised (Richardson 1946: 45). Nonetheless, the basic defining steps of the One-step, Foxtrot and Tango were accepted by those present. The committee had though failed to address recommendations for improving the performance of the Waltz. Richardson did not let slip this goal from his sights, again canvassing opinion from leading teachers and exhibition dancers on the future of the dance and setting an agreed steer from the pedagogic profession as a principal agenda item for the next conference.(64).

In May 1921 the third informal conference was held at the Grafton Galleries which attracted almost three hundred teachers who spent much time discussing the Waltz as well as the arrival of the 'shimmy' step. A second smaller committee was set up 
which incorporated comparatively young and more current additions in West End, teachers Florence Purcell and Josephine Bradley, and exhibition dancers Mlle Lunina, Mr Sielle and Monsieur Pierre.(65) Conveyed by report in October 1921, the recommendations of this committee on the One-step, Foxtrot, Waltz and Tango were supplemented by a general note on the overall style to be adopted (Richardson 1946: 46-47)..Detailed direction on how to dance the Waltz, however, was lacking. Indeed, the committee's bald recommendation of "step-step-feet together" to be performed forwards, backwards and turning to Waltz music was dismissed by one commentator as 'jejune'. (66).

\section{Towards Restitution of the Queen of Dances}

Manifestly the pedagogic profession alone could not advance sufficient ammunition to win the battle for the restitution of the Waltz onto the modern dance floor. Additional strategies were required on a similar national scale to that of the Grafton conferences, but with personnel who could exercise greater allure than the professional dancing teachers. To be recruited Into the arsenal were the winners of prestigious dance competitions who, frequently rubbing shoulders with aristocracy and celebrities, exuded the glamour of the night life of London's West End clubland. Part Two of this inquiry into how the long loved Waltz was rescued and reformed as a vital modern ballroom form, alongside its younger companions on London's fashionable dance floors, will focus on the role of competitions, the model of the exhibition dancer, and the aesthetic legacies embodied in the Waltz's most high profile proponents. 


\section{Acknowledgements}

Ideas and material for Part One of this article were explored in a keynote address 'Popular Dancing around the First World War' at the Society for Dance Research's 2014 conference Dancing in the Shadow of the First World War. I am especially grateful to Chris Jones for her unceasing encouragement and interest in this work and for ongoing discussion and stimulation from colleagues in the Sub-Study Group on Round Dances- Nineteenth-Century Derived Couple Dances of the Study Group on Ethnochoreology (International Council for Traditional Music).

I would like to thank the following for their helpful and timely support: Eleanor Fitzpatrick, Philip Richardson Library Archive, Royal Academy of Dance, London; Sarah Jardine-Willoughby, Library, Imperial Society of Teachers of Dancing and Kornelia Cepok, Archives and Special Collections, Library, University of

Roehampton, London. My thanks also to librarians at the British Library,London and the Bodleian Library, Oxford.

I thank the Mary Evans Picture Library and I am especially grateful to Jon Gray for his kind assistance and generosity in granting permission to reproduce several pictures from The Dancing Times.

\section{Notes}

1. For a general account of this process, written by one of its major advocates and protagonists, see Richardson (1946). For a more recent and critically distanced survey, see McMains (2006: 80-86); also, this present discussion passim.

2. For an overview of waltzing's diverse manifestations see the entry on 'Waltz 'in International Encyclopedia of Dance and Aldrich (1990). 
3. Questions of appropriation, especially cultural, came to the fore in the discipline of dance studies largely through Desmond (1997). The migration and transmission of popular dance practices are enmeshed, of course, in issues of authenticity, class, race, capitalism, politics, and values: see Dodds (2011) for a helpful consideration of previous scholarship relating to theoretical issues in dance and popular culture.

4. Among those in English are Nettl (1946), Reeser [1949], Katz (1973) and Yaraman (2002).

5. For France, see Jacotot (2013) and for the United States, Robinson (2015).

6. For descriptions see Silvester (1936, 1974) and Moore (2006 [1963]).

7. See discussion below.

8. For an overview see Richardson's own account (1946), chapter vii. Also entry on Richardson in Oxford Dictionary of National Biography.

9. For detail on Silvester, see his autobiography (1958) and ISTD (2004). See also his entry in the Oxford Dictionary of National Biography.

10. The dance repertoire was largely split on social class lines in the two decades prior to the First World War, those in the lower eschelons opting for set choreographies known as sequence dances and the upper middle classes preferring improvised forms of couple dancing. See Buckland (2011: 187-88).

11. With the exception of Abra, Nott and Zimring noted above.

12. See Richardson (1946), chapter v and Buckland (2011: 166-69).

13. For a more detailed comparison of the old and new ways of waltzing in the first decade of the twentieth century see Buckland (2013).

14. On ragtime music generally see Berlin (1980) and for a musical example from the period refer to ((https://www.youtube.com/watch?v=pMAtL7n -rc 
15. Undated in Edward Scott's scrapbook collection, 'What the Press Says.' I am grateful to his granddaughter Miss Gillian Booth for access to this material. On the general reaction to the Tango in England see Collier (1992).

16. On the habanera rhythm and tango development in general see entry for tango in Oxford Music Online:

http://www.oxfordmusiconline.com/subscriber/article/grove/music/27473?q=tango\&s earch=quick\&pos=1\& start=1\#firsthit accessed 6 July 2016

Listen to the Library of Congress National Jukebox which includes recordings of El Choclo by the Victor Orchestra in 1912

http://www.loc.gov/jukebox/recordings/detail/id/2905 and the Maurice Tango, featuring a banjo solo http://www.loc.gov/jukebox/recordings/detail/id/6347 accessed 6 July 2016. On the older style of Waltz see Scott's technical description (1887: 108114).

17. Letter from Muriel Simmond [sic] Dancing Times, October 1920: 15.

18. The entry for foxtrot in Oxford Music Online defines: 'Music for the foxtrot is in 4/4 time, with the primary accent on the first beat of the measure and a secondary accent on the third beat.'

http://www.oxfordmusiconline.com/subscriber/article/grove/music/A2219055?q=foxtr ot\&search=quick \&pos=2\& start=1\#firsthit A contemporary recording by the London Dance Orchestra of a foxtrot c.1919 can be heard on https://www.youtube.com/watch?v=5vrlU2WNP5w

For foxtrot steps as recommended in England see, for example D'Egville (1919: 5561).

19. Dancing Times, August 1916, p. 306. 
20. Dancing Times, December 1918: 59. On the instrumentation of these early jazz bands for dancing in London see Parsonage (2005: 133-134).

21. See Castle, 1914: 71. Richardson cites the description of tango specialist Muriel Simmons on the pre-war execution of the Tango 'corte' (1946: 26) and in the Dancing Times October 1919: 3 notes a tendency 'among some dancers to introduce a suspicion of tango' into the Waltz referring to this feature as a '"throwback"'. For a contemporary performance example of the music (although American in provenance) see the recording of Hesitation Waltz (interestingly subtitled Valse Boston) by the Victor Military band recorded in Camden New Jersey in 1914: http://www.loc.gov/jukebox/recordings/detail/id/3858 accessed 24 February. 22. Dancing Times, August 1916: 298, 309.

23. Listed in the World Catalogue http://www.worldcat.org/title/underneath-the-starssaunter-pf/oclc/498366605?ht=edition\&referer=di accessed 24 February. For a contemporary recording go to http://www.loc.gov/jukebox/recordings/detail/id/4926 accessed 23 February 2016, Victor Dance Orchestra, recorded in New Jersey, USA 1916.

24. Dancing Times September 1916? Bradley credits Harding with its introduction to the London clubs, ' Memories of the Ballroom 1910-1935, III. The Fox-Trot', Dancing Times, October, 1935: 55-58, (56).

25. 'What they say about "The Saunter"', Dancing Times, September 1916: 330, 332. There was some debate and disapproval over the movements referred to as the 'Shimmie' at this time. See The Sitter Out [alias Richardson], Dancing Times, October 1919: 3 and “"Three-Step” and "Shimmy”. Old Friends in a New Guise', Dancing Times, December, 1919:167. For discussion see Cresswell (2006:62-63). 26 Dancing Times, October 1916: 13. 
27. Mr H Blackeby, member of the British Association of Teachers of Dancing (BATD) quoted in Dancing Times, October 1916:15. For further discussion on social dance repertoires according to class and geography at this time, see Buckland, 2011: 187-89.

28. Dancing Times, September 1916: 332.

29. On the Versatile Four, an African-American group appearing in England between 1913 and 1926 see Parsonage, 2005: 114, 117. Their instrumentation included two banjolines, piano and drums plus vocals. The group was certainly playing a fast and rhythmically vigorous style in the early years of the war although this may have been to make an impact in recording for publicity purposes. Their 1916 recording of Down Home Rag available at https://www.youtube.com/watch?v=GfDubf6TnHc accessed 24 February is cited by Parsonage as an early example of ragtime music that prefigures jazz.

30. Dancing Times, August, 1919: 525.

31. The Coon Orchestra, earlier known as the Clef Club Orchestra, was led by Dan Kildare (pianist) and appeared in the United Kingdom, playing for dancing mostly at the Savoy Hotel and Ciro's Club 1915-1920. Dan Kildare had played for Joan Sawyer's Persian Garden Orchestra in New York. Its instrumentation was wider than that of the Versatile Four, sometimes including the violincello and string bass. An example of their driving upbeat foxtrot recorded in London 1917 can be heard on https://www.youtube.com/watch?v=FsoY EFllhl accessed 19 November 2016.

32. On the Original Dixieland Jazz Band (hereafter ODJB) see Parsonage 2005: 121-43. The band's instrumentation included clarinet, cornet, drums, piano and trombone, producing a deliberate raucous sound. For an early recording of the OJDB's dance music, often heralded as the beginning of jazz, refer to its recording of 
the 'Dixie jass [sic] band one-step' Original Dixieland Jazz Band recorded New York 1917

http://www.loc.gov/jukebox/recordings/detail/id/4669.

33. September 1916: 341. The Sitter Out [alias Richardson] similarly complained after the war that 'where there are nigger bands it [the valse] is not played more frequently than is necessary, as presumably the niggers realise they cannot do justice to it', Dancing Times, October 1919: 3.

34. Dancing Times, November, 1919: 86. Muriel Simmons wrote that the Americans introduced the three step into London in the spring of 1918, Dancing Times October 1919: 19. It soon went out of fashion as a separate form; see Dancing Times, August, 1919:482.

35. See Richardson, 1946: 38-39 and Pierre (1919: 10-11, 14-15).

36. Bradley (1947:12). See also Dancing Times, February,1919: 155. When executed on a zig zag rather than the semi-circular pathway, the step produced a greater rolling movement. This was called the Tango Jazz Roll by Pierre who also likened it to the Tango's 'Scissors' step (1919: 16). It possibly owed its source, as noted above, to the habit of using tango steps to other rhythms. Mouvet (1915: 84) for example, advised that for 'the accomplished dancer, most of the Tango steps are easily applied to the fox trot by a slight change of rhythm. The Cortez, the Promenade and the Scissors can all be done with good effect.'

37. Dancing Times, November, 1919: 87, 86.

38. Dancing Times, August, 1919: 525; according to Bradley (1947: 12) this style was adopted to maintain equilibrium in the Jazz Roll.

39. Dancing Times, August, 1919: 545. Richardson also noted this fashion in Dancing Times, October 1919: 3. See the photograph of Pierre and his partner in 
Pierre (1919) which is more like the hold demonstrated by Maurice Mouvet at the first 1920 Informal Conference at the Grafton Galleries (see below).

40. Richardson (1946: 38) and Bradley (1947: 13). Richardson in Dancing Times, February, 1919:155 dates this introduction of the 'Jazz or American roll' to Murray's Club being several months before the American troops arrived (1917). Bradley (1935: 56) describes Morgan performing this turn in the rhythm of 'slow, quick quick' without pause and dates its first appearance by Morgan at Murray's Club to 1918. 41. Already, as noted by Maurice Mouvet (1915: 82) a slow walk 'allowing two beats to each one' was in use in the United States as part of a number of moves to the music. By 1919 the fox trot walk in England was 'done leisurely and somewhat stealthily, as if sensing the rhythm of the music.' (D'Albert, 1919: 59).

42. For general discussion on moral panic in relation to couple dancing in Europe see Knowles (2009) and Bakka, Saarkoski, Buckland, and Wharton (forthcoming).

43. Richardson in Dancing Times, November, 1919: 83.

44. Dancing Times, February 1919: 147. See too 'The Valse Revival. Mr. Archibald Joyce's Opinion', Dancing Times, December 1919: 227. Joyce's earlier experience of playing for dancing included piano accompaniment to ballet teachers Katti Lanner and John D'Auban [ibid.].

45. November, 1918: 36. Trained in ballet technique, Shilling unsurprisingly, as Richardson observed, was strongly in favour of the 'old valse'. Other contributors to the article were exhibition dancer and teacher Mrs Vernon Castle, musical comedy dancer and actor Dorma Leigh, professional ballet dancer and social dancer Phyllis Bedells, and ballroom teachers Madame Vandyck, Miss Harding and Muriel Simmons. 46. So too did over-use of the Three-step [Richardson] November 1919:87.

47. Letter by Vasco, Dancing Times, January, 1919: 141 
48. "Promenade Position. Any figure in which the dancers open out fanwise, the gentleman's right side remaining in contact with his partner's left." Silvester and Richardson (1936: 75).

49. P.J.S.R. [Richardson] Dancing Times, February, 1919: 157.

50 Dancing Times, October 1919: 3; [Richardson], Dancing Times November 1919: 83.

51. "They valse better in Blackpool" Dancing Times, September 1919: 540.

52. Dancing Times, November 1919: 107. For a near-contemporary recording refer to Three o'clock in the Morning by the Blackpool Tower Orchestra conducted by Mr J Woof Gaggs (1923) on YouTube https://www.youtube.com/watch?v=MVJNI-ikimE . See also Dancing Times, October 1919: 49 for evidence of London's slower pace for waltzing. Richardson noted that in the Versatile Four's slow rendition of waltzes at the Grafton Galleries "the spirit of the dance seems to evaporate." Dancing Times, December 1919: 159. For other notable dance band leaders' opinions on Foxtrot and Valse tempi see Dancing Times October 1919: 49.

53. On the history of Blackpool's famous association with ballroom dancing see Richardson (1946: 144-46) and the Blackpool Dance Festival's official website http://www.blackpooldancefestival.com/?page id=11790.

54. Dancing Times, April 1920: 526, 528.

55. 'Our Conference of Ballroom Teachers', Dancing Times, June 1920: 703. This article lists other notable attendees and includes photographs of the demonstration by Mouvet and Hughes from the Daily Mail (pages 697, 699, 701, 703). Related correspondence followed on pages $703,705,707$ and 709 .

56. Dancing Times June 1920: 703. Further discussion on the informal conferences and their outcomes can be found in Richardson (1946: 42-47), Nott (2002: 162, 2013: 
441-43, 2015: 225-27), Cresswell (2006), (Abra, 2009: 27-64, 2012) and Buckland (2011: 190-94). The proposed first committee comprised: Madame Edith Baird, Mr Charles d'Albert, Mr H Bloodworth, Mrs Louis D'Egville, Monsieur Georges Fontana, Miss Harding, Mr W F Hurndall, Monsieur Maurice, Mr Alec Mackenzie, Mr D G MacLennan, Miss Muriel Simmons, Mr Edward Scott, Miss Smurthwaite, Major Cecil Taylor and Madame Vandyck.

57. See feature on D'Albert in the Dancing Times May 1913: 562-63 and his obituary in the same journal, December 1923: 214 .

58. Simmonds [sic] (1920). Also entry in Haskell and Richardson (1932: 121). Simmons was noted in the 1911 census as a teacher of dancing.

59. The Mackenzies taught in London until 1928 when Alec (Alexander) opened a school in New York. The Mackenzies were especially prominent in their promotion of the post-war Parisian style of ballroom tango. (Haskell and Richardson, 1932: 193). During the war years, Mrs Mackenzie continued to teach and hold dances, instructing her husband in the foxtrot when home on leave in 1915 (Dancing Times August: 363). 60. Entry for MacLennan in Haskell and Richardson (1932: 94). MacLennan came from a prestigious Scottish family of pipers and dancers, studied ballet with Alexander Genée in London and published Highland and Traditional Scottish Dances in 1950.

61. For Harding and her pre-war enterprise see Buckland (2011: 156-59); for Vandyck's international reach see Dancing Times December 1913: 168 and August 1914: 684. Vandyck (born Mary Alice Longman) appears to have been instructed into the profession by West London resident aunt Sabina Olivieri (1847-1901), setting up independently by 1901 in Hampstead and later in central London. More generally on her contribution to the teaching of ballroom dancing see her obituary notice in Dancing Times, November 1954: 123 and discussion below. 
62. The 'Arlington' (1905), the 'Carlton' (1907), the 'Hurndilla' (1911) and with his wife Madame Low Hurndall, the 'Maxina' which took first prize in 1917 in the annual competition for new sequence dances organized by the British Association of Teachers of Dancing (BATD). Hurndall's initial suggestion to engineer a national uniform teaching method was intended to bring together four pedagogic associations: the United Kingdom Alliance (UKA), the Imperial Society of Dance Teachers (ISDT), the BATD and the National Association of Teachers of Dancing (NATD). See his letter in the Dancing Times, November 1917: 43. He was also the proprietor of The Ballroom. 63. Edith Maria Baird (born c.1882) was the daughter of an Ipswich dancing teacher. She also created set dances, winning a prize alongside Cecil Taylor at the 1919 ISDT Congress (Dancing Times, September 1919: 593). As an example of her pedagogic portfolio, see Dancing Times, September 1920: 937, 939. Jeanie Adine Smurthwaite (born 1871) was a member of the ISDT Council by 1913 (Dance Journal, vi, July 1913: 1) and ran The Adine School of Dancing in central London which offered a wide portfolio. See Haskell and Richardson (1932: 122) on her other dance pedagogic affiliations.

64. 'What about the Valse?' Dancing Times April 1921: 5??, 573, 575.

65. The second committee comprised: Madame Baird, Miss Bradley, Miss Harding, Mlle Lunina, Miss Simmons, Miss Purcell, Miss Smurthwaite, Mr Bloodworth, Mr D’Albert, Mr MacLennan, Mr Mackenzie, M Pierre and Mr Sielle. Dancing Times June 1921: 727. Purcell was a generalist dance teacher but very active in teaching modern ballroom dancing. Bradley had recently established her own school specializing in modern ballroom dancing and of course was the foremost professional exponent of the Foxtrot following her success with G.K. Anderson at the Embassy and Ivory Cross (January 1921) competitions. Lunina had danced with the Imperial Russian Ballet 
Company before turning to exhibition work; see photograph of her performing at Sherrys in Brighton in a balletic lift, wearing pointe shoes and a mid-length tutu Dancing Times October 1920: 47; Monsieur Pierre (aka French born Pierre Jean Philippe Zurcher-Magolle c.1888-1963) went on to a prestigious teaching career and is credited with the introduction of the Latin American style of ballroom dancing to Britain. (Haskell and Richardson, 1932: 108). Robert Sielle, aka Cecil Leon Roberts (1895-1983) enjoyed a brief career as a professional dancer and married his partner Annette Mills, later a noted English actor and children's TV presenter. See http://www.npg.org.uk/research/conservation/directory-of-british-framemakers/s.php and Richardson (1946: 63-64).

66. Correspondence from $\mathrm{H}$. Kirkland-Whittaker 'The True Rhythm of the Waltz', The Ballroom Pictorial, vol 3, no 7, September 1922: 310.

\section{References}

Abra, Allison Jean. (2009). On with the Dance: Nation, Culture, and Popular Dancing in Britain, 1918-1945. PhD Department of History, University of Michigan

Abra, Allison. (2012). The Evolution of Popular Dancing in Britain in the 1920s. In Leisure and Cultural Conflict in Twentieth-Century Britain edited by Brett Bebber. Manchester: Manchester University Press

Abra, Allison. (2017). Dancing in the English Style: Consumption, Americanisation and National Identity in Britain, 1918-50. Manchester: Manchester University Press Aldrich, Elizabeth. (1990). A New Look at an Old Dance: The Waltz, $5^{\text {th }}$ Hong Kong International Dance Conference Proceedings, vol. 1: 11-26. 
An Expert (1923) The Modern Ballroom Dance Instructor by an Expert . Geographica (copy in British Library)

Anon. (1920). The Marvels of Murrays. Some Impressions of the well-known Beak Street Club' Dancing World, vol. 1, no 6.October, p 22 PAGES ALL HERE?

Berlin, Edward A. (1980). Ragtime: A Musical and Cultural History. Berkeley and Los Angeles: University of California Press

Bradley, Josephine. (1947). Dancing through Life. London: Hollis and Carter

Buckland, Theresa Jill. (2011a). Society Dancing. Fashionable Bodies in England, 1870-1920. Basingstoke, Hampshire: Palgrave Macmillan

Buckland, Theresa Jill. (2011b). From the Artificial to the Natural Body: Social Dancing in Britain, 1900-1914. In Alexandra Carter and Rachel Fensham eds, Dancing Naturally. Nature, Neo-Classicism and Modernity in Early TwentiethCentury Dance. Basingstoke, Hampshire: Palgrave Macmillan

Buckland, Theresa Jill. (2013). Dancing out of time: The Forgotten Boston of Edwardian England in Dodds Sherril and Susan C. Cook, eds Bodies of Sound: Studies across Popular Music and Dance. Farnham, Surrey: Ashgate Castle, Irene and Vernon. (1914). Modern Dancing. New York: World Syndicate Company

Collier, Simon.(1992) "Hullo Tango!" The English Tango Craze and its After-Echoes. In The Land that England Lost: Argentina and Britain, A Special Relationship edited by Alistair Hennessy and John K King. London: British Academy Press 
Cook, Susan C. (1998). Passionless Dancing and Passionate Reform: Respectability, Modernism and the Social Dancing of Irene and Vernon Castle. In The Passion of Music and Dance: Body, Gender and Sexuality edited by William Washabaugh. Oxford: Berg

Cook, Susan C. (1999). Watching Our Step: Embodying Research, Telling Stories in Elaine Barkin and Lydia Hamessley eds Audible Traces: Gender, Identity and Music Zurich: Carciofoli Verlagshaus

Cree, Aubrey McMahon. (1920). Handbook of Ballroom Dancing. London and New York: John Lane

Cresswell, Tim. (2006). 'You Cannot Shake that Shimmie Here': Producing Mobility on the Dance Floor', Cultural Geographies, 2006, 13, 55-77. Also published (2006) as a chapter in his On the Move: Mobility in the Western World London and New York: Routledge

D'Albert, Charles. 1919. The Encyclopaedia of Dancing. London: T. M. Middleton D’Egville, Geoffrey. (1919). How and What to Dance. London: C. Arthur Pearson Desmond, Jane C. (1997) 'Embodying Difference: Issues in Dance and Cultural Studies'. In Jane C. Desmond, ed. Meaning in Motion: New Cultural Studies of Dance. Durham and London: Duke University Press Dodds, Sherril. (2011). Dancing on the Canon. Embodiments of Value in Popular Dance. Basingstoke, Hampshire: Palgrave Macmillan 
George-Graves, Nadine. (2009). "Just Like Being At The Zoo": Primitivity and Ragtime Dance in Julie Malnig (ed), Ballroom, Boogie, Shimmy Sham, Shake: A Social and Popular Dance Reader, Urbana and Chicago: University of Illinois Press Gottschild, Brenda Dixon. (2000). Waltzing in the Dark: African American Vaudeville and Race Politics in the Swing Era. Basingstoke, Hampshire: Palgrave Macmillan Haskell, Arnold and Richardson, P. J. S. eds (1932). Who's Who in Dancing 1932. London: The Dancing Times

ISTD (Imperial Society of Teachers of Dancing). (2004). I00 years of Dance. A History of the ISTD Examinations Board. London: ISTD Examinations Board Jacotot, Sophie. (2007). The Inversion of Social Dance Transfers between Europe and the Americas at the Turn of the Twentieth Century, CORD Proceedings, pp. $106-111$

Sophie Jacotot. (2013). Danser à Paris dans L'entre-Deux-Guerres. Lieux, Pratiques et Imaginaires des Danses de Société des Amériques (1919-1939). Paris: Nouveau Monde éditions

Katz, Ruth. (1973) The Egalitarian Waltz, Comparative Studies in Society and History, 15 , no. 3, 368-77

Knowles, Mark. (2009). The Wicked Waltz and Other Scandalous Dances. Outrage at Couple Dancing in the $19^{\text {th }}$ and early $20^{\text {th }}$ Centuries. Jefferson, North Carolina and London: McFarland and Co. 
Martin, Christopher Tremewan. (2010). How the Waltz was Won: Towards a Waltz Aesthetic. Dissertation. University of Maryland (College Park, Md)

http://hdl.handle.net/1903/10752

McMains, Juliet (2006). Glamour Addiction. Inside the American Ballroom Dance Industry. Middletown, Connecticut: Wesleyan University Press

Moore, Alex. (2006). Ballroom Dancing. Keighley, West Yorkshire: Pomona Press. Several editions, first published (1963) London: A \& C Black

Mouvet, Maurice. (1915). Maurice's Art of Dancing. New York: G. Schirmer

Nettl, Paul. (1946). 'The Birth of the Waltz', Dance Index, 5, no. 9, New York: DanceIndex Ballet Caravan,

Nott, James J. (2002). Music for the People. Popular Music and Dance in Interwar Britain. Oxford: Oxford University Press

Nott, James J. (2011). 'The Plague Spots of London': William Joynson-Hicks, the Conservative Party, and the Campaign against London's Nightclubs, 1924-29 in Classes, Cultures, and Politics. Essays on British History for Ross McKibbin ed. Clare V. Griffiths, James J. Nott and William Whyte, Oxford: Oxford University Press Nott, James. (2013) Contesting Popular Dancing and Dance Music in Britain during the 1920s, Cultural \& Social History. The Journal of the Social History Society, vol 10, no. 3 , pp. $439-56$

Nott, James J. (2015). Going to the Palais: A Social and Cultural History of Dancing and Dance Halls in Britain, 1918-1960. Oxford: Oxford University Press 
Parsonage, Catherine. (2005). The Evolution of Jazz in Britain, 1880-1935.

Farnham, Surrey: Ashgate

Pierre, Monsieur. (1919). How to Jazz. A Simple Guide to the 1919 Dances. London: E J Larby

Richardson, P J. S. (1946). A History of English Ballroom Dancing (1910-45). London: Herbert Jenkins

Robinson, Danielle. (2006). "Oh, You Black Bottom!” : Appropriation, Authenticity, and Opportunities in the Jazz Dance Teaching of 1920s New York, Dance Research Journal, 38, 1\&2, pp. 19-42

Robinson, Danielle. (2009) Performing American: Ragtime Dancing as Participatory Minstrelsy, Dance Chronicle, 32,1, pp. 89-126

Robinson, Danielle. (2010). 'The Ugly Duckling: The Refinement of Ragtime Dancing and the Mass production and Marketing of Modern Social Dance, Dance Research, 28, 2, pp. $179-99$

Robinson, Danielle. (2015) Modern Moves. Dancing Race During the Ragtime and Jazz Eras. Oxford: Oxford University Press

Roshwald, Aviel and Stites, Richard, eds. (1999). European Culture in the Great War The arts, entertainment and propaganda, 1914-1918. Cambridge: Cambridge University Press

Scott, Edward. (1887). Dancing and Dancers, Or Grace and Folly. London: Ward and Downey

Scott-Atkinson, E. (1928). 'The Ballroom Today', The Dancer, vol 1, no 1,page? 
Silvester, Victor. (1927). Modern Ballroom Dancing. .London: Herbert Jenkins

Silvester, Victor. (1935). 'The Valse (b) 1921-1935.' Dancing Times October: 53-55.

Silvester, Victor. 1958. Dancing is my Life. An Autobiography. London: Heinemann

Silvester, Victor. (1974). Modern Ballroom Dancing: History and Practice. London:

Barrie \& Jenkins

Silvester, Victor and Richardson, Philip J. S. (1936). The Art of the Ballroom.

London: Herbert Jenkins

Simmonds [sic] Muriel (1920). Dancing Times, October: 15.

Sweetsur, R. (1920) Some Productive Benefits of Dancing, Dancing World. Vol 1,No

6, October : 7 .

The Clubman (1922) 'Round the West End Ballrooms', The Ballroom, 3, 1 March, 5

Yaraman, Sevin H. (2002). Revolving Embrace: Sex, Steps and Sound, Hillsdale, New York: Pendragon Press

Zimring, Rishona (2013). Social Dance and the Modernist Imagination in Interwar Britain. Farnham, Surry: Ashgate 